\title{
Effect of COVID-19 on agricultural production and food security: A scientometric analysis
}

\author{
Collins C. Okolie (iD ${ }^{1} \&$ Abiodun A. Ogundeji (id ${ }^{1 凶}$
}

Coronavirus disease has created an unexpected negative situation globally, impacting the agricultural sector, economy, human health, and food security. This study examined research on COVID-19 in relation to agricultural production and food security. Research articles published in Web of Science and Scopus were sourced, considering critical situations and circumstance posed by COVID-19 pandemic with regards to the shortage of agricultural production activities and threat to food security systems. In total, 174 published papers in BibTeX format were downloaded for further study. To assess the relevant documents, authors used "effects of COVID-19 on agricultural production and food security (ECAP-FS) as a search keyword for research published between 2016 and April 2021 utilising bibliometric innovative methods. The findings indicated an annual growth rate of about $56.64 \%$, indicating that research on ECAP-FS increased over time within the study period. Nevertheless, the research output on ECAP-FS varied with 2020 accounting for 38.5\%, followed by 2021 with $37.9 \%$ as at April 2021. The proposed four stage processes for merging two databases for bibliometric analyses clearly showed that one can run collaboration network analyses, authors coupling among other analyses by following our procedure and finally using net2VOSviewer, which is embedded in Rstudio software package. The study concluded that interruptions in agricultural food supply as a result of the pandemic impacted supply and demand shocks with negative impacts on all the four pillars of food security.

\footnotetext{
${ }^{1}$ Department of Agricultural Economics, University of the Free State, Bloemfontein, South Africa. ${ }^{凶}$ email: ogundejiaa@ufs.ac.za
} 


\section{Introduction}

he coronavirus disease (COVID-19) has created an unusual situation globally (Alam and Khatun, 2021). Barely a year ago early in the year 2020, the unusual nature of coronavirus caused most governments to implement stringent steps in their countries to restrain the virus's spread. The novel coronavirus (SARS-CoV-2) disease impacted economies throughout the world, disproportionately impacting individuals who were already susceptible to poverty and hunger (Laborde et al., 2020a; Ceballos et al., 2020). In late December 2019, the virus was discovered in Wuhan City, Hubei Province, China. The pandemic caused by COVID-19 presented a major danger to human health, the economy, and food security in both industrialised and emerging nations (Mottaleb et al., 2020; Carroll et al., 2020; Alam and Khatun, 2021). Lessons learned from China revealed that various COVID-19 countermeasures such as lockdown in the country hampered production. This poses a significant risk to the long-term food supply (FAO, 2020), and has a negative impact on the economy, resulting in economic decline and crisis (Bai, 2020). It is important to understand that certain precautional and control efforts compromise agricultural production (Singh et al., 2021).

The virus wreaked havoc on the agricultural production sector, which is at the heart of the food chain (Pu and Zhong, 2020). The global spread of coronavirus resulted in the greatest economic downturn since World War Two (Hanna et al., 2020; Xu et al., 2021). The epidemic's major impact on agricultural labour input was the restriction of labour mobility. Farmers were not permitted to just go out and gather in any way except to purchase essentials. This resulted in a manpower scarcity and reduced mass production efficiency. For instance, due to a scarcity of migrant experts, producers from Sichuan, Hunan, and Hubei in the grainproducing districts in China (south-eastern coastal district) were not able to sow their crops in good time (Pu and Zhong, 2020). Furthermore, wheat and pulse harvesting in northwest India was hampered due to a lack of migrant labour (Dev, 2020). Vegetable farmers in Ethiopia incurred not just financial loss as a result of overstocked items, but also from a lack of vital inputs (Tamru et al., 2020). Before the pandemic, suppliers may have planted six hectares in a single day, but due to the difficulties in finding tractor drivers during the pandemic, they were only able to cover three hectares a day (Pu and Zhong, 2020). Any interruptions in agricultural food supply will indeed result in supply and demand shocks, which will have an immediate effect on the agricultural sector of the economy with long-term economic performance and food security implications (Gregorio and Ancog, 2020).

Food security refers to a situation where all individuals at all time have continuous physical and economic access to sufficient, safe, and nutritious food to fulfil their dietary needs and food choices for an active and healthy lifestyle (Elsahoryi et al., 2020). Food security has been jeopardised both directly and indirectly as a result of the virus's destabilisation of food systems and the effects of lockdowns on family revenue and physical access to food (Devereux et al., 2020). The presence of coronavirus disease has a negative impact on all the four pillars of food security, viz. availability of food, accessibility of food, utilisation of food, and stability of food (Nechifor et al., 2021; Laborde et al., 2020b). According to Genkin and Mikheev (2020), the report by the Food and Agriculture Organization (FAO), World Trade Organization, and World Health Organization (WHO) note the threat of a food catastrophe triggered by the current coronavirus pandemic, with a risk of a global "food shortage" owing to interruptions in the trade industry's supply chain. According to the report, global commerce contracted by roughly $20 \%$ in 2020 , with $90-120$ million human beings falling into severe destitution and over 300 million facing food security issues in emerging nations. To combat the COVID-19 pandemic, world leaders implemented steps to decrease the number of commodities carried by sea, air and land, as well as labour migration at national and global levels. These variables contributed to a widespread disturbance in agricultural output and food distribution systems, posing challenges to the transportation of food and agricultural resources (Genkin and Mikheev, 2020).

Present literature centred on the effect of coronavirus on food security or effect of coronavirus on agricultural production (Elsahoryi et al., 2020; Nchanji and Lutomia, 2021). Despite the growing body of research on coronavirus, agricultural production, and food security, few studies have attempted to conduct a thorough assessment of the literature and map the present level of scientific knowledge on the effect of coronavirus on agricultural production and food security (ECAP-FS). Hence, the goal of this research was to examine the effect of coronavirus on agricultural production and food security by employing bibliometric analyses techniques to recognise keywords in connection to two core aspects, namely the most prolific or productive writers and the most collaborative nations, and then to examine the strength of their association over the study period. The study characterised intellectual processes further by visualising and recognising the advancement of the co-citation network, cooperation network, and trends in ECAP-FS research. This research will not only aid in the identification of present research on ECAP-FS, but also contributes to an improved comprehension of the scientific knowledge of coronavirus and its impact on agricultural production, food security, and the investigation of its evolution via published papers included in the Web of Science (WoS) and Scopus databases. Because one database is unlikely to provide a comprehensive picture of knowledge and trends in a field, the authors recommend a four stage processes to achieve a merged database that integrates WoS and Scopus and then deletes identical publications using RStudio or R-package to perform author coupling, keywords co-occurrence network visualisation, university collaboration networks, and others using net2VOSviewer. This study will be among the few that explains how to integrate two datasets and utilise them to conduct different network associations in bibliometrix R-package (RStudio v.4.0.3 software).

\section{Method and data collection}

The scientometric technique was used to retrieve articles relating to the effect of coronavirus on agricultural production and food security. This method used resources from two different databases, WoS and Scopus, for the systematic reviews. Table 1 shows the eligibility and exclusion criteria that was used to access the relevant documents. The various steps employed in the review process were (databases, identification, screening, eligibility, merging, duplicate removal and included documents) (see Fig. 1). Processing and analysis of the data were then applied to the remaining documents. Scientometrics is defined as the research approach utilised in analysing and assessing science, innovation, and technology by applying statistics and quantitative analysis to explain the distribution and visualisation patterns of research within a specific nation, issue, field or institution (Orimoloye and Ololade, 2021). Scientometric evaluations have been used to analyse scientific trends and outputs, as well as the evolution of research, author productivity, journals, and nations, as well as to discover and measure international collaboration (Orimoloye and Ololade, 2021).

Resources. WoS and Scopus were the two-database used for this study. WoS is a database collection administered by Thomson Reuters Institute of Scientific Information (ISI) that contains databases on humanities, social sciences, biology (i.e., Biosis), science (i.e., Core Collection) and computers (i.e., Inspec). WoS was 


\section{Table 1 Inclusion and exclusion criteria.}

\begin{tabular}{|c|c|c|}
\hline Criterion & Eligibility & Exclusion \\
\hline \multicolumn{3}{|l|}{ Web of Science } \\
\hline Document type & Article & Conference paper, book chapter, review \\
\hline Source type & Journals & Book series, book \\
\hline Publication stage & Final & Article in press \\
\hline WoS categories & $\begin{array}{l}\text { Food Science tech, Science Multidisciplinary } \\
\text { Environmental Science, Agricultural Sciences }\end{array}$ & $\begin{array}{l}\text { Econometrics and Finance, Biochemistry, Medicine, Genetics and Molecular } \\
\text { Biology, Economics, Management and Accounting, Business. }\end{array}$ \\
\hline Language & English & Non-English \\
\hline Period & Between 2016-April 2021 & $<2016$, \& >April 2021 \\
\hline \multicolumn{3}{|l|}{ Scopus } \\
\hline Document type & Article & Conference paper, book chapter, review \\
\hline Source type & Journals & Book series, book \\
\hline Publication stage & Final & Article in press \\
\hline Subject area & $\begin{array}{l}\text { Environmental Science, Social Sciences, Agricultural } \\
\text { and Biological Sciences }\end{array}$ & $\begin{array}{l}\text { Business, Economics, Genetics and Molecular Biology, Energy, Engineering, } \\
\text { Management and Accounting, Medicine, Biochemistry, Business, } \\
\text { Econometrics and Finance. }\end{array}$ \\
\hline Language & English & Non-English \\
\hline Period & Between 2016-April 2021 & $<2016, \&>$ April 2021 \\
\hline
\end{tabular}

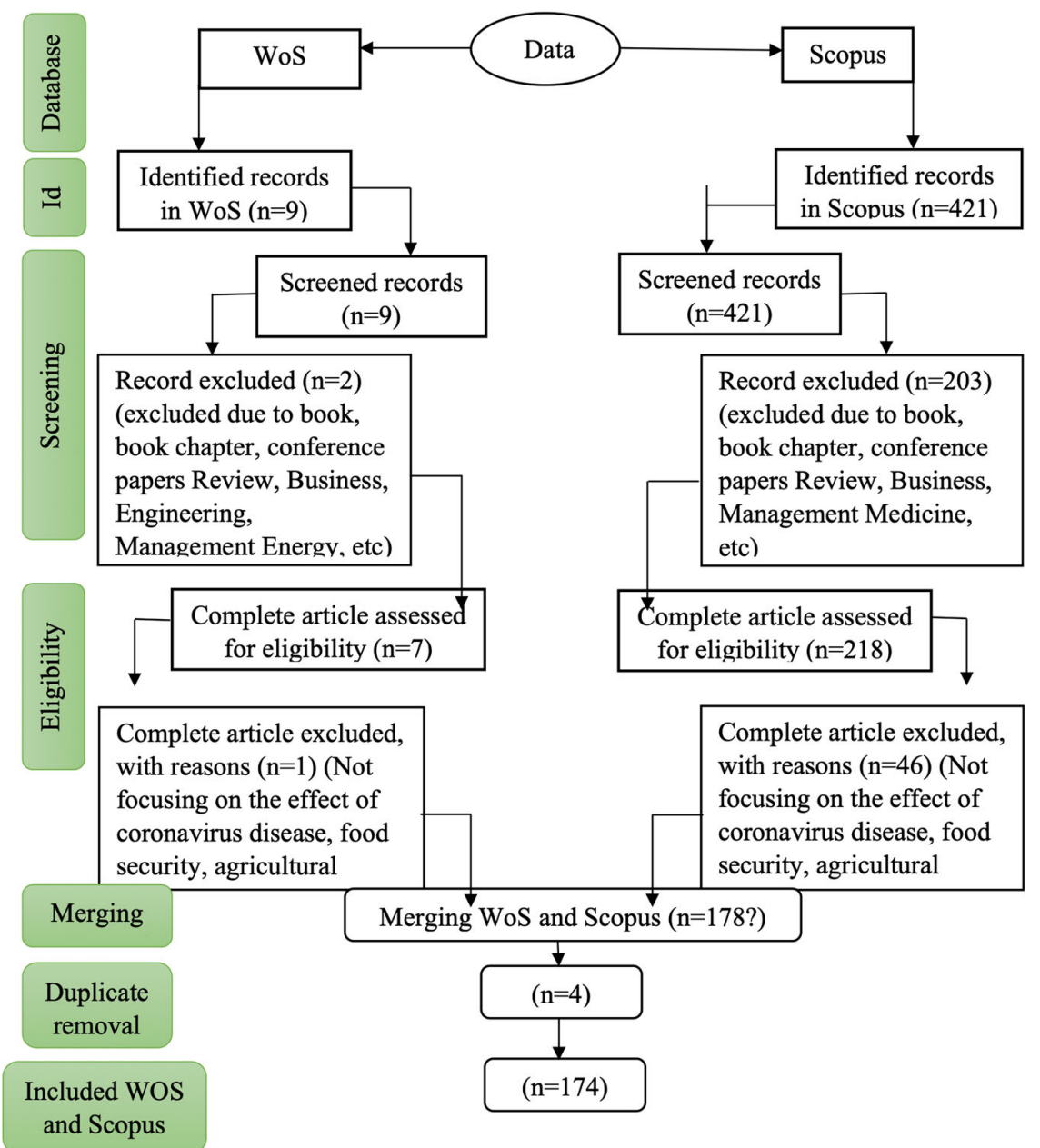

Fig. 1 The research flow chart (modified from Shaffril et al., 2018). WoS: Web of Science.

previously the only and biggest accessible database for bibliometric analysis. However, Scopus that was launched by Elsevier, with ease of use in universities throughout the globe emerged as a key rival for doing such studies (Echchakoui, 2020). Scopus has the largest abstract and citation databases with over 22,800 journals from 5000 publishers worldwide was used in the review (Shaffril et al., 2018). Moreover, It is the most comprehensive interdisciplinary database of peer-reviewed literature in the social sciences, and is generally acknowledged and utilised for quantitative analyses (GuerreroBaena et al., 2014).

Criteria for eligibility and exclusion. Various qualifying and exclusion criteria were considered. Title-based search for rapid 
Table 2 The systematic review search string.

Source

Used keywords

"corona*" OR "covid" OR "covid19" OR "covid_19" OR "covid-19" OR "SARS-CoV-2 OR "2019-nCoV") AND ("agricultural production*") AND ("food security" $\left.{ }^{\star \prime}\right)$ )))))

Scopus

$$
\text { Title("impact" OR "effect*") AND of ("coronavirus" OR "corona - virus" OR "corona_virus" OR "corona virus" OR }
$$

"corona*" OR "covid" OR "covid19" OR "covid_19" OR "covid-19" OR "SARS-CoV-2" OR "2019-nCoV") AND ("agricultural production" ${ }^{\star}$ ) AND ("food security ${ }^{\star \prime}$ )

visibility and retrieval was used. According to Ekundayo and Okoh (2018), a title-specific search offers the advantages of low loss, considerable retrieval, and sensitivity when compared to other types of searches such as a topic, field, or author search. First, concerning literature type, only journals and final articles were selected, which meant Article in Press, etc., were excluded. Secondly, non-English articles were excluded. Thirdly, a period of 6 years was used followed by the subject area, which focused on Environmental, Social, Agricultural, and Biological Sciences (Table 1) (Shaffril et al., 2018).

Systematic review process. To explore the current literature on ECAP-FS, we conducted a comprehensive literature review according to the rules provided by Tranfield et al. (2003). The systematic review process for this study involved four stages. The review process was performed in April 2021. The first stage was the selection of databases (WoS and Scopus). The second stage pinpointed keywords utilised for the search process. Based on prior research, keywords similar and related to the effect of COVID-19 on agricultural output and food security were used with a total of $(n=9,421)$ published records found on WoS and Scopus, respectively (Table 2). The third stage was screening. Out of $(n=9,421)$ papers eligible for evaluation at this stage, a total of $(n=7,203)$ papers were excluded. The fourth stage was eligibility where the complete articles were accessible. Following a thorough review, a total of $(n=1,46)$ publications were eliminated since some did not focus on the effect of coronavirus on agricultural production and food security. The fifth stage was merging the two documents $(n=6,172=178)$. The sixth stage was the removal of duplicates $(n=4)$. The last round of evaluation yielded a total of $(n=174)$ papers for qualitative analysis (Fig. 1).

Processing and analysis of data. The research assessed data obtained for scientometric investigation utilising RStudio v.4.0.3 software with bibliometrix R-package and net2VOSviewer after reading the articles relevant to the study. The data were imported into RStudio, transformed to a bibliographic data frame, and normalised for duplicate matches (Aria and Cuccurullo, 2017; Ekundayo and Okoh, 2018). Net2VOSviewer (net,vos.path = NULL) embedded in RStudio v.4.0.3 software were used for visualisation. The VOSviewer programme created by Van Eck and Waltman (2009) is often used to visualise and evaluate a bibliometric network. Hamidah et al. (2021) and Zhang and Yuan (2019) made use of VOSviewer to analyse a bibliographic map on energy performance. Park and Nagy (2018) used VOSviewer to examine building control bibliographic data, and Van Eck and Waltman (2017) analysed citation-based clustering in the field of astronomy and astrophysics using VOSviewer. The research made use of Net2VOSviewer embedded in R studio to make visualisation maps, such as authors coupling, keyword cooccurrence network, and university collaboration network, based on bibliographic data. Each circle on the VOSviewer visual map represents a word. The term activity is represented by the circle and text size. The big circle and text show the chosen terms in a field. The distance between the two words reflects the degree of their association. In this case, the relationship between two words will be greater if the distance between them is small (Hamidah et al., 2021).

Web of Science and Scopus database merging for bibliometric analysis. The authors suggest the following four stage approach to combine the two databases shown in Fig. 1 and Table 3.

As soon as required articles were sourced, we downloaded the documents separately from WoS and Scopus databases. For WoS, we clicked on export, which redirected us to another window where we selected "other file formats" under record content, and "BiTeX" under file format before we clicked export. For Scopus, we went to export document setting where we ticked all relevant boxes including "BibTeX" before clicking export. The second step was to transform (WoS.bib and Scopus.bib) to "bibtex" files. Here we used $\mathrm{R}$ or Rstudio software by loading the bibliometrix package "install.packages" ("bibliometrix"), and "library(bibliometrix)", After that we specified the pathway using the command file $1<-$ "path/savedrecs.bib" and file $<$ - "path/scopus.bib" for WoS and Scopus files, respectively. After that we converted file $(1 \& 2)$ using command " $\mathrm{f} 1<-$ convert $2 \mathrm{df}(\mathrm{file} 1$, dbsource $=$ "isi", format = "bibtex")" and "f2<-convert $2 \mathrm{df}($ file 2 , dbsource $=$ "scopus", format = "bibtex")" for WoS and Scopus respectively. We merged the two databases in R/Rstudio. For this operation to be successful, we used the command " $j<-$ mergeDbSources(f1, f2, remove.duplicated $=$ FALSE)". Finally, the duplicate documents were removed using the command " $\mathrm{M}<-$ duplicatedMatching $(\mathrm{j}$, Field $=$ "TI",tol $=0.95)$ ". We performed a bibliometric analysis for bibtex file in Rstudio, using Aria and Cuccurullo's (2017) techniques and scripts in $\mathrm{R}$, and utilising the net2VOSviewer for keywords co-occurrence network, collaboration networks of universities, authors coupling, amongst others.

Bibliometric analyses results. During the survey period, 174 papers were published on ECAP-FS; their characteristics are shown in Table 4 . The research had 851 authors, with a cooperation index of 5.1 and a document/author ratio of 0.20 (4.89 authors/document). Except for nine authors who published alone, all 842 authors were part of multi-author publications.

During the research period, an average of 6.0 citations per document were recorded. Lotka's law scientific output for ECAPFS study revealed a constant of 0.70 and beta coefficient of 3.88 , with a Kolmogorov-Smirnoff goodness-of-fit of 0.94 . Table 5 and Fig. 2 displays published research on ECAP-FS from 2016 to April 2021 in conjunction with the total citation of papers on average by year. The yearly pace of development was 56.64, with a mean overall of $12 \pm 6$, indicating that ECAP-FS research increased over time. This outcome agrees with the work of El Mohadebe et al. (2020) who stated that the number of published articles increased exponentially since the start of the COVID-19 pandemic. The rise in COVID-19 research reflects that it is a major danger to human health, the economy, and food security in industrialised and emerging nations (Carroll et al., 2020; Mottaleb et al., 2020; Alam and Khatun, 2021). 
Table 3 Procedure for merging and removing of duplicates from Web of Science (WoS) and Scopus databases for bibliometric analyses.

\begin{tabular}{|c|c|c|c|}
\hline Stage & Objective & Procedures & Action \\
\hline One & $\begin{array}{l}\text { Converting and exporting your } \\
\text { documents from WoS and Scopus } \\
\text { databases in "BibTeX" to be used for } \\
\text { bibliometrix analysis. }\end{array}$ & $\begin{array}{l}\text { After sourcing your articles, } \\
\text { export the sourced documents } \\
\text { from each database in "BibTeX" } \\
\text { format. }\end{array}$ & $\begin{array}{l}\text { In WoS: first select other file formats which will prompt another } \\
\text { window for you. Select "Full record and cited references" before } \\
\text { selecting "BibTeX" in record content and file format respectively. } \\
\text { For Scopus, in export document settings, select BibTeX and } \\
\text { export. }\end{array}$ \\
\hline Two & $\begin{array}{l}\text { Converting the documents in } \\
\text { "WoS.bib" and Scopus.bib to } \\
\text { "bibtex" file. }\end{array}$ & $\begin{array}{l}\text { Use R or Rstudio software to load } \\
\text { the bibliometrix package. }\end{array}$ & $\begin{array}{l}\text { In Rstudio/R software do the following: } \\
\text { >install.packages("bibliometrix") >library(bibliometrix). You can } \\
\text { as well see https://cran.r-project.org/web/ } \\
\text { packages.bibliometrix/vignettes/bibliometrix-vignette.vignette. } \\
\text { Load the two files from the two databases using the codes below. } \\
\text { file1<- "path/savedrecs.bib" } \\
\text { file2<- "path/scopus.bib" } \\
\text { f1<- convert2df(file1, dbsource = "isi", format = "bibtex") } \\
\text { f2<- convert2df(file2, dbsource = "scopus", format = "bibtex") }\end{array}$ \\
\hline Three & $\begin{array}{l}\text { Merging the two databases in } \\
\text { Rstudio or R. }\end{array}$ & $\begin{array}{l}\text { Use R or Rstudio software to } \\
\text { merge the two files. }\end{array}$ & $\mathrm{j}<-$ mergeDbSources $(\mathrm{f} 1, \mathrm{f2}$, remove.duplicated $=$ FALSE) \\
\hline Four & $\begin{array}{l}\text { Removing duplicates of the merged } \\
\text { databases. }\end{array}$ & & M<-duplicatedMatching(j, Field = "TI",to $=0.95)$ \\
\hline
\end{tabular}

Table 4 Web of Science and Scopus key information about the data.

\begin{tabular}{ll} 
Articles & $\mathbf{1 7 4}$ \\
\hline Duration & $2016: 2021$ \\
Sources (Journals) & 90 \\
Average years from publication & 1.12 \\
Citations per document on average & 6.023 \\
Average citations per year per document & 1.825 \\
Keywords Plus (ID) & 1229 \\
Authors' Keywords (DE) & 708 \\
Authors & 851 \\
Author appearances & 910 \\
Documents written by a single author & 9 \\
Multi-authored document authors & 842 \\
Documents per author & 0.204 \\
Authors per document & 4.89 \\
Co-authors per document & 5.23 \\
Collaboration index (CI) & 5.1 \\
\hline
\end{tabular}

\section{Table 5 Scientific production in a year.}

\begin{tabular}{lll} 
Year & Number of published articles & $\begin{array}{l}\text { Average total citations } \\
\text { per year }\end{array}$ \\
\hline 2016 & 7 & 11.8 \\
2017 & 6 & 2.0 \\
2018 & 13 & 4.8 \\
2019 & 15 & 4.3 \\
2020 & 67 & 3.7 \\
2021 & 66 & 0.0 \\
\hline
\end{tabular}

During the survey period, research production varied, peaking in 2020 with $38.5 \%(67 / 174)$ of the total research output, followed by 2021 with 66 research articles accounting for $37.9 \%(66 / 174)$ during the same time. This result is liable to change when additional papers pertaining to ECAP-FS are published in 2021. The average total number of citations for published papers changed over time, peaking in 2016 (average = 11.8). Furthermore, the findings of this analysis identified the top 20 most

\begin{tabular}{|c|c|c|c|c|}
\hline $\mathbf{S} / \mathbf{N}$ & Authors & Articles & Authors & $\begin{array}{l}\text { Articles } \\
\text { fractionalised }\end{array}$ \\
\hline 1 & Gong B & 6 & Gong B & 2.650 \\
\hline 2 & Baudron $\mathrm{F}$ & 3 & Salata S & 1.500 \\
\hline 3 & Peng W & 3 & Barrett C & 1.000 \\
\hline 4 & Zhang S & 3 & Bayu T & 1.000 \\
\hline 5 & Aguilera-Huertas J & 2 & Cristiano S & 1.000 \\
\hline 6 & Alcon F & 2 & $\begin{array}{l}\text { Graddy- } \\
\text { Lovelace G }\end{array}$ & 1.000 \\
\hline 7 & Aldaco R & 2 & Petetin L & 1.000 \\
\hline 8 & Alvarez S & 2 & Van D P J & 1.000 \\
\hline 9 & Astier M & 2 & Woertz E & 1.000 \\
\hline 10 & Bala A & 2 & Baudron F & 0.900 \\
\hline 11 & Brites C & 2 & Astier M & 0.833 \\
\hline 12 & Ceballos F & 2 & $\begin{array}{l}\text { Orozco- } \\
\text { Ramrez Q }\end{array}$ & 0.833 \\
\hline 13 & Chen $\mathrm{K}$ & 2 & Chen $\mathrm{K}$ & 0.750 \\
\hline 14 & Deng $X$ & 2 & Wang C & 0.700 \\
\hline 15 & Erokhin V & 2 & Ceballos F & 0.667 \\
\hline 16 & Fullanaipalmer P & 2 & Kannan S & 0.667 \\
\hline 17 & Gonzlez-Rosado M & 2 & Kramer B & 0.667 \\
\hline 18 & Gregorini P & 2 & Zhang S & 0.650 \\
\hline 19 & Gu Z & 2 & Deng $X$ & 0.583 \\
\hline 20 & Hoehn D & 2 & Gregorini $P$ & 0.583 \\
\hline
\end{tabular}

prolific authors from 2016 to April 2021. Table 6 shows Gong B as the most productive author over the time, with six papers accounting for $3.45 \%$ of the total research publications on ECAPFS. The following were placed second on the list: Baudron F, Peng $\mathrm{W}$, and Zhang $\mathrm{S}$ who published three research articles each accounting for $1.7 \%$ of the total published research articles within the study period. The rest of the 17 authors published two articles within the same year. The quantity of a researcher's academic output demonstrates their efficacy and propensity for conducting quality research (Orimoloye et al., 2021a)

Citation analysis reveals how many times a specific research article has been cited in other scientific articles. More cited research articles are considered significantly more influential than 


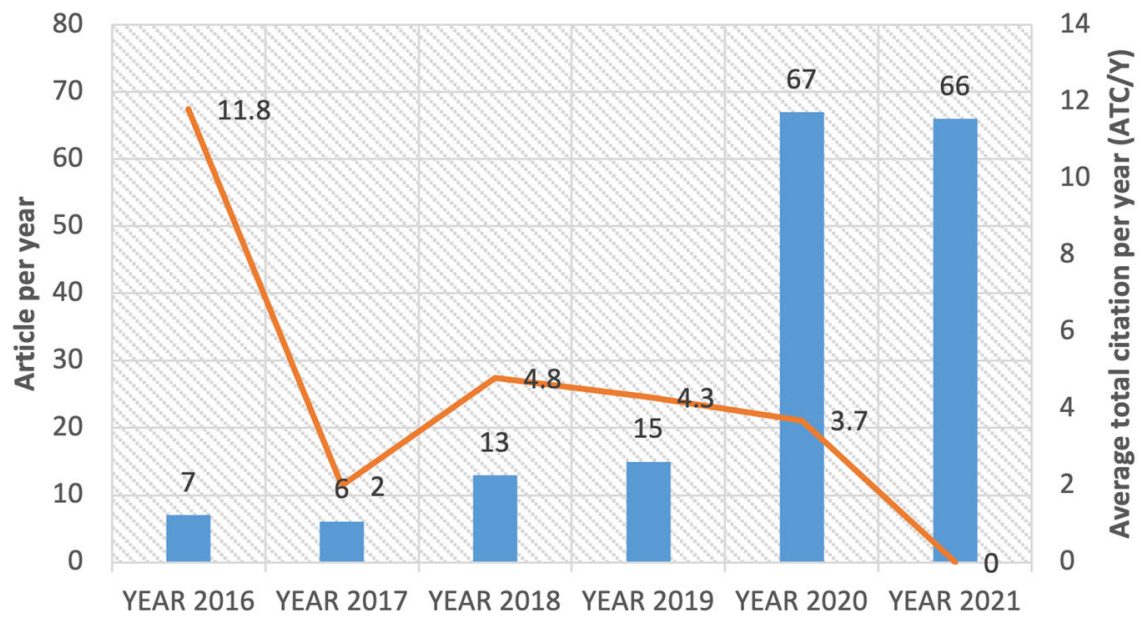

Article

ATC/Y

Fig. 2 From 2016 through April 2021, annual scientific productivity for ECAP-FS publications indexed in Web of Science and Scopus. ATC/Y average total citations of articles published per year. NB: The yearly percentage rate of increase was 56.64 .

\begin{tabular}{|c|c|c|c|}
\hline SN & Paper & TC & TC/YR \\
\hline 1 & Foyer et al. 2016, Nature Plants & 244 & 40.67 \\
\hline 2 & Hart et al. 2018, Functional Ecology & 60 & 15.00 \\
\hline 3 & Smiraglia D, 2016, Environmental Research & 52 & 8.67 \\
\hline 4 & Millar NS, 2016, Oecologia & 43 & 7.67 \\
\hline 5 & Tesfahunegn GB, 2016, Applied Geography & 42 & 7.00 \\
\hline 6 & KC et al. 2018, Plos One & 39 & 9.75 \\
\hline 7 & Pu and Zhong, 2020, Global Food Security & 23 & 11.50 \\
\hline 8 & Provenza FD, 2019, Frontiers in Nutrition & 21 & 7.00 \\
\hline 9 & $\begin{array}{l}\text { Lares-Orozco Mf, 2016, Journal of Cleaner } \\
\text { Production }\end{array}$ & 17 & 2.83 \\
\hline 10 & $\begin{array}{l}\text { Salata S, 2017, Management of Environmental } \\
\text { Quality }\end{array}$ & 16 & 3.20 \\
\hline 11 & Zhang, 2020, China Agricultural Economic Review & 15 & 7.50 \\
\hline 12 & $\begin{array}{l}\text { Garca Kerdan I, 2019, Journal of Cleaner } \\
\text { Production }\end{array}$ & 15 & 5.00 \\
\hline 13 & $\begin{array}{l}\text { Panukhnyk O, 2019, Global Journal of } \\
\text { Environmental Science and Management }\end{array}$ & 15 & 5.00 \\
\hline 14 & Petetin, 2020, European Journal of Risk Regulation & 14 & 7.00 \\
\hline 15 & Liu J, 2020, Science of the Total Environment & 14 & 7.00 \\
\hline 16 & Mascarenhas A, 2019, Land Use Policy & 13 & 4.33 \\
\hline 17 & Nayak Pk, 2018, Ecological Indicators & 13 & 3.25 \\
\hline 18 & Parajuli R, 2018, Science of the Total Environment & 13 & 3.25 \\
\hline 19 & Rivieccio R, 2017, Sustainability (United States) & 13 & 2.60 \\
\hline 20 & Liu J, 2019, Land Use Policy & 12 & 4.00 \\
\hline
\end{tabular}

articles with fewer citations (Mishra et al., 2017; Nyam et al., 2020). Table 7 shows the top 20 papers on ECAP-FS in terms of citations in the field throughout the time. The list was compiled using the publications with the most citations (Echchakoui, 2020). In this research on ECAP-FS, Foyer et al. 2016 "Nature Plants" placed first with a total of 244 citations. Hart et al. 2018 "Functional Ecology" took second place with 60 citations, followed by Smiraglia D. 2016 "Environmental Research" with 52 citations during the same time period. Millar NS 2016 "Oecologia" and Tesfahunegn GB 2016 "Applied Geography" rated fourth and fifth with 43 and 42 citations, respectively. With 39,23 and 21 citations, respectively, KC et al. 2018 "Plos One," $\mathrm{Pu}$

\begin{tabular}{|c|c|c|c|c|c|}
\hline Nation & Articles & Freq & SCP & MCP & MCP_Ratio \\
\hline China & 28 & 0.192 & 22 & 6 & 0.214 \\
\hline USA & 19 & 0.130 & 9 & 10 & 0.526 \\
\hline United Kingdom & 12 & 0.082 & 9 & 3 & 0.250 \\
\hline Italy & 9 & 0.062 & 5 & 4 & 0.444 \\
\hline Spain & 8 & 0.055 & 7 & 1 & 0.125 \\
\hline Australia & 5 & 0.034 & 2 & 3 & 0.600 \\
\hline India & 5 & 0.034 & 2 & 3 & 0.600 \\
\hline Mexico & 5 & 0.034 & 2 & 3 & 0.600 \\
\hline Germany & 4 & 0.027 & 1 & 3 & 0.750 \\
\hline Brazil & 3 & 0.021 & 2 & 1 & 0.333 \\
\hline Canada & 3 & 0.021 & 1 & 2 & 0.667 \\
\hline Korea & 3 & 0.021 & 0 & 3 & 1.000 \\
\hline Belgium & 2 & 0.014 & 2 & 0 & 0.000 \\
\hline Ethiopia & 2 & 0.014 & 1 & 1 & 0.500 \\
\hline France & 2 & 0.014 & 0 & 2 & 1.000 \\
\hline Kenya & 2 & 0.014 & 1 & 1 & 0.500 \\
\hline Nigeria & 2 & 0.014 & 1 & 1 & 0.500 \\
\hline Portugal & 2 & 0.014 & 1 & 1 & 0.500 \\
\hline Qatar & 2 & 0.014 & 0 & 2 & 1.000 \\
\hline Romania & 2 & 0.014 & 2 & 0 & 0.000 \\
\hline
\end{tabular}

and Zhong, 2020 "Global Food Security," and Provenza FD 2019 "Frontiers in Nutrition" placed sixth, seventh, and eighth. As shown in Table 8 , the leading active writers were connected with institutions in both emerging and developed countries, including China (28), the United States (19), the United Kingdom (12), Italy (9), Spain (8), Australia (5), India (5), and Mexico (5). With the exception of China, the majority of the articles were from developed countries. China, the United States of America, United Kingdom, Italy, and Spain, among other countries, contributed the most articles in ECAP-FS, which is line with the work of Mottaleb et al. (2020). According to Orimoloye et al. (2021b), research funding and scholarships have had a significant impact on the research output of many countries. As a result, this study indicates that economic assistance could help in the advancement of research in the area of ECAP-FS. Furthermore, during the 


\begin{tabular}{|c|c|c|c|}
\hline SN & Country & TC & AAC \\
\hline 1 & Italy & 112 & 12.44 \\
\hline 2 & China & 107 & 3.82 \\
\hline 3 & USA & 81 & 4.26 \\
\hline 4 & United Kingdom & 76 & 6.33 \\
\hline 5 & Ethiopia & 47 & 23.50 \\
\hline 6 & Canada & 40 & 13.33 \\
\hline 7 & Mexico & 22 & 4.40 \\
\hline 8 & Germany & 21 & 5.25 \\
\hline 9 & France & 18 & 9.00 \\
\hline 10 & Spain & 18 & 2.25 \\
\hline 11 & India & 17 & 3.40 \\
\hline 12 & Ukraine & 15 & 7.50 \\
\hline 13 & Brazil & 14 & 4.67 \\
\hline 14 & Australia & 13 & 2.60 \\
\hline 15 & Antigua & 12 & 12.00 \\
\hline 16 & Hungary & 11 & 11.00 \\
\hline 17 & Portugal & 8 & 4.00 \\
\hline 18 & Zimbabwe & 7 & 7.00 \\
\hline 19 & Bolivia & 6 & 6.00 \\
\hline 20 & Korea & 6 & 2.00 \\
\hline
\end{tabular}

research period, the total citation of published papers on average by each nation differed from one nation to another. Table 9 shows the top 20 citations by nation for ECAP-FS research papers. The data indicated that the most mentioned nations were industrialised ones, while China, a developing country, placed second among the most often referenced nations. The exceptional success of China research suggests that the nation performs well in sponsoring field research, possibly because the coronavirus originated in Wuhan City of China (Mottalab et al., 2020). Italy leads the way with 112 total citations and an average article citation of 12.44 for research papers published during the study duration, China was second with 107 citations and an average article citation of 3.82. During the same time period, the United States, the United Kingdom, Ethiopia, and Canada were placed third, fourth, fifth, and sixth, with total number of citations (average article citations) of 81 (4.26), 76 (6.33), 47 (23.50), and 40 (13.33), respectively.

This analysis also uncovered the most relevant sources for published academic research on ECAP-FS between 2016 and April 2021, as shown in Table 10. Sustainability (Switzerland) was first with a total of 23 scientific papers on ECAP-FS. Agricultural Systems and Journal of Cleaner Production were ranked second and third with a total of 13 and 10 articles respectively. Global Food Security and Science of The Total Environment were rated fourth with eight articles each. Land was ranked fifth with five articles while Food Security, International Journal of Environmental Research and Public Health, Plos One were ranked sixth with four published articles each. Environmental Research and Journal of Integrative Agriculture rated seventh with three published articles on ECAP-FS throughout the review period.

Concerns are growing about the influence of COVID-19 on agricultural production, which could pose a significant threat to long-term food security and food supply (Pu and Zhong, 2020). Table 11 summarises the top 20 academics' most relevant terms. In addition, Table 11 displays the most important keywords linked to ECAP-FS research, including keywords-plus (ID) as well as author keywords (DE). COVID-19, Food Security, Agriculture, Climate Change, Sustainable Development, Agricultural Production, Biodiversity, China, and Sustainability were among the nine keywords shared by keywords-plus (ID) and author
Table 10 Most relevant sources related to agricultural production and food security.

\begin{tabular}{lll} 
SN & Sources & Articles \\
\hline 1 & Sustainability (Switzerland) & 23 \\
2 & Agricultural Systems & 13 \\
3 & Journal of Cleaner Production & 10 \\
4 & Global Food Security & 8 \\
5 & Science of The Total Environment & 8 \\
6 & Land & 5 \\
7 & Food Security & 4 \\
8 & International Journal of Environmental Research and & 4 \\
& Public Health & \\
9 & Plos One & 4 \\
10 & Environmental Research & 3 \\
11 & Journal of Integrative Agriculture & 3 \\
12 & Land Use Policy & 3 \\
13 & Agriculture (Switzerland) & 2 \\
14 & Agriculture and Human Values & 2 \\
15 & China Agricultural Economic Review & 2 \\
16 & Current Developments in Nutrition & 2 \\
17 & Environmental Research Letters & 2 \\
18 & Frontiers in Nutrition & 2 \\
19 & Journal of Productivity Analysis & 2 \\
20 & Water (Switzerland) & 2
\end{tabular}

keywords (DE). Eleven keywords were peculiar to authors' keywords (Resilience, Ecosystem Services, Food Systems, COVID-19 Pandemic, Food Supply Chain, India, Land Take, Life Cycle Assessment, Nutrition, Conservation, and Dietary Diversity), and nine keywords were unique to keywords-Plus (Food Supply, Human, Article, Food Production, Land Use, Agricultural Robots, Agricultural Land, Controlled Study, and Cultivation). The distinct author keywords explicitly defined what COVID-19 affected as well as the means or elements engaged in the process (Nutrition, Dietary Diversity, Ecosystem Services, Resilience, Conservation, Food Systems, and Food Supply Chain of People). COVID-19 $(n=27,15.5 \%)$, Food Security $(n=25$, $14.4 \%)$, Agriculture $(n=18,10.3 \%)$, Climate Change $(n=9$, $5.2 \%)$, Sustainable Development $(n=5,2.9 \%)$, Agricultural Production $(n=4,2.3 \%)$, Biodiversity $(n=4,2.3 \%)$, China $(n=4,2.3 \%)$, COVID-19 Pandemic $(n=4,2.3 \%)$ were author keyword phrases related with the detection of ECAP-FS.

The keyword analysis identified Food Security in 35 (20.1\%) and $25(14.4 \%)$ published papers by keyword-plus and author keyword, respectively, while Agricultural was found in 28 (16.1\%) and $18(10.3 \%)$ published papers by keyword-plus and author keyword, respectively. By author keyword and keyword-plus, Agricultural Production was detected in 4 (2.3\%) and 28 (16.1\%) publications, respectively. In the ECAP-FS study field, Climate Change was detected in $26(14.9 \%)$ and $9(5.2 \%)$ papers by keyword-plus and author keyword, respectively. The review indicates that research on ECAP-FS emphasised these agricultural-related issues several times, implying that COVID19 has an effect on agriculture, agricultural production, sustainable development, food security, and food supply of the general public, which is exacerbated by climate change, and is a major danger to food security, economy and human health (Mottaleb et al., 2020).

The connection between influential authors, keywords, journals, and trending topics was investigated using co-citation network analysis (Leydesdorff, 2009). Articles are said to be co-cited when they are cited and appear in other publications' reference lists (Nyam et al., 2020). The top 20 authors coupling in Fig. 3 explains the authors coupling on ECAP-FS-related research. Every node in 


\section{Table 11 The most pertinent keywords related to agricultural production and food security.}

\begin{tabular}{lllll} 
& Author keywords (DE) & Art. (\% of 174) & Keywords-Plus (ID) & Art. (\% of 174) \\
\hline 1 & COVID-19 & $27(15.5)$ & Food Security & $35(20.1)$ \\
2 & Food Security & $25(14.4)$ & Agricultural Production \\
3 & Agriculture & $18(10.3)$ & Agriculture & $28(16.1)$ \\
4 & Climate Change & $9(5.2)$ & Food Supply \\
5 & Resilience & $9(5.2)$ & Climate Change \\
6 & Ecosystem Services & $8(4.6)$ & Human & $28(16.1)$ \\
7 & Food Systems & $5(2.9)$ & Article \\
8 & Sustainable Development & $5(2.9)$ & Food Production \\
9 & Agricultural Production & $4(2.3)$ & China & Sustainable Development \\
10 & Biodiversity & $4(2.3)$ & Land Use & Agricultural Robots \\
11 & China & $4(2.3)$ & COVID-19 \\
12 & COVID-19 Pandemic & $4(2.3)$ & Biodiversity \\
13 & Food Supply Chain & $4(2.3)$ & Agricultural Land \\
14 & India & $4(2.3)$ & Sustainability \\
15 & Land Take & $4(2.3)$ & Controlled Study \\
16 & Life Cycle Assessment & $4(2.3)$ & Cultivation \\
17 & Nutrition & $4(2.3)$ & & $19(10.9)$ \\
18 & Sustainability & $4(2.3)$ & $18(10.3)$ \\
19 & Conservation & $3(1.7)$ & $16(9.2)$ \\
20 & Dietary Diversity & $3(1.7)$ & $14(8.6)$ \\
\end{tabular}

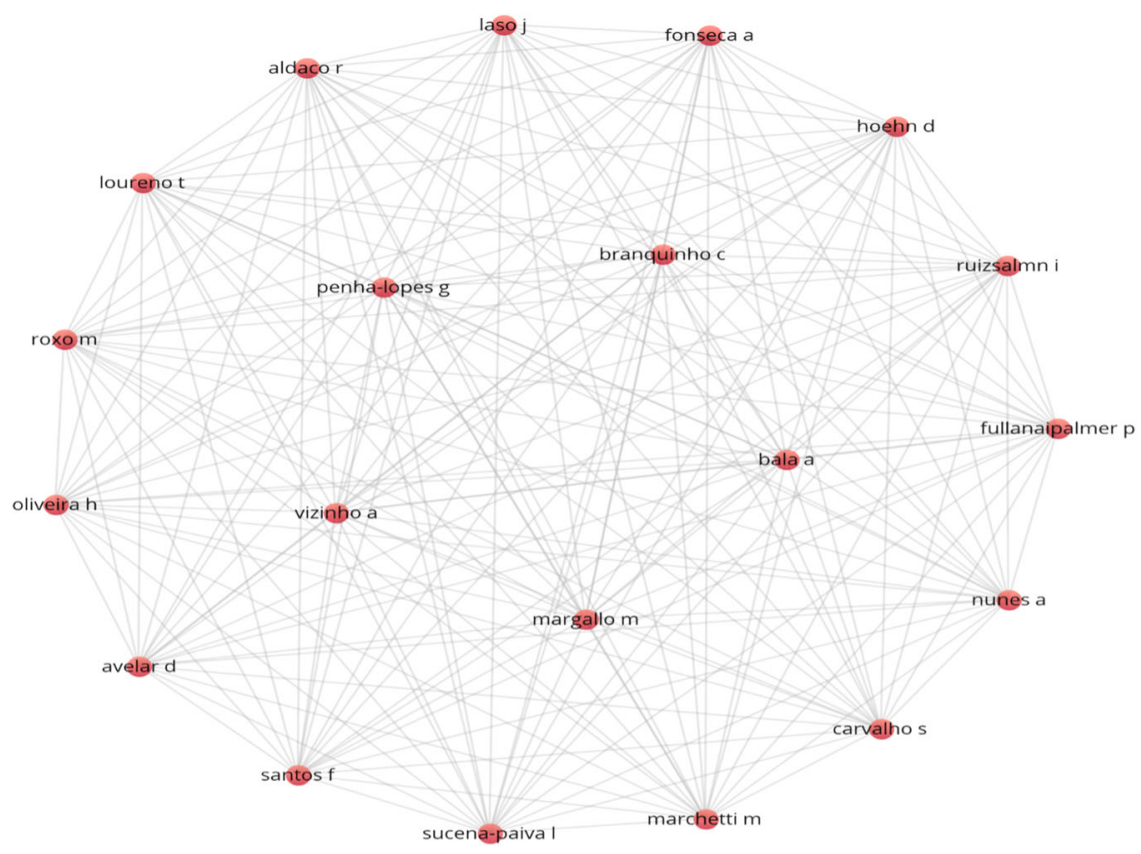

Fig. 3 Authors coupling. The top 20 authors coupling on agricultural production and food security published articles. (Every node in the network symbolises a distinct author who is linked to others. Connecting lines reflect author-to author linking routes).

the network symbolises a distinct author who is linked to others. Connecting lines reflect author-to-author linking routes. The number of lines from each node correlates to the number of published papers that referenced the writer. The cluster of authors network, which comprises 20 nodes (authors), has no less than 18 interconnections. Other indicators of often expressed ideas and frameworks linked to ECAP-FS include nation collaboration (Fig. 4) and university collaboration network (Fig. 5).

Authors with multiple affiliations have made significant contributions to nation and university collaborative networks (Figs. 4 and 5). Our findings indicated that studies on ECAP-FS were conducted at institutions in both advanced and developing nations between 2016 and April 2021. The Wageningen University (Netherland), the China Agricultural University (China), the Zhejiang University (Asia), and University of Pretoria (South Africa) had the greatest collaboration network on ECAP-FS studies followed by the University of Western Australia (Australia), University of Leeds (UK), University of Alberta (Canada), University of Sydney (Australia), Case Western Reserve University (USA), Chinese University of Hong Kong (China) and the International Crop Research Institute. The University of Oxford was the only university that did not collaborate with any of the universities during the study period. Figure 4 depicts the networks of collaboration on ECAP-FS for 27 


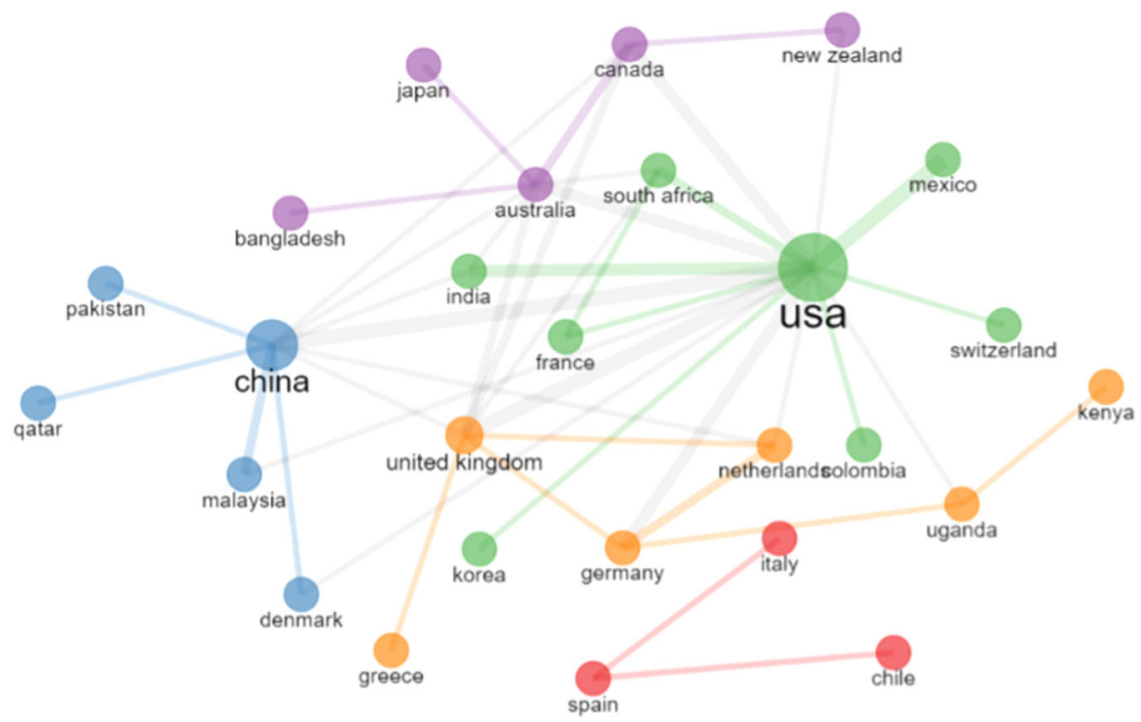

Fig. 4 Nation's collaboration network. The top 27 nation collaboration networks on agricultural production and food security. (Each node represents a country, and the lines represent their collaboration).

countries. The number of collaboration paths varied from one to 17. The number of partnerships was highest in the USA $(n=17)$, followed by China $(\mathrm{n}=10)$, Australia $(n=8)$, the United Kingdom $(n=8)$, Canada $(n=5)$, the Netherlands $(n=4)$, Germany $(n=4)$, South Africa $(n=4)$, Uganda $(n=3)$, India $(n=3)$, Malaysia $(n=2)$, Denmark $(n=2)$, France $(n=2)$, Spain $(n=2)$, and New Zealand $(n=2)$. The remaining nations had one collaboration network. This outcome is consistent with El Mohadab et al. (2020) as the analysis of a nation's collaboration is a vital type of analysis, because it allows for the visualisation of the most influential nations in a given field of research, revealing the level of scientific cooperation between the countries. The following network colour codes were prominent: light green for the USA network; light blue for the China network; purple for the Australia network; orange for the United Kingdom network; and brown for the Spain network.

Figure 6 depicts the top 30 keywords of co-occurrence network, the related visualisation and the association strength of ECAP-FS. The co-occurrence of author keywords was examined to illustrate the research hotspots in ECAP-FS. The threshold for keyword cooccurrence was set at 10, and 30 keywords out of 708 were categorised as visualisation elements. The distance between the components of each pairings indicated topic similarity and relative strength. Individual term clusters were allocated different colours of circles. The network in Fig. 6 depicts three different clusters, each reflecting a branch of research in the ECAP-FS literature. The number of publications in which the keywords cooccurred was shown by the connections between specific keywords. The main themes with the highest overall connection strength in the ECAP-FS literature were COVID-19, Food Security, Agriculture, and Climate Change.

The ECAP-FS scientific field has three subfields (clusters of author keywords), which are as follows:

- The blue cluster includes terms such as COVID-19, Food Supply, Food Production, China, Food Security, and Agricultural Production.'

- The red cluster grouped the keywords Agricultural Land, Catering Services, Environmental Protection, Humans, Meat, Human, Food Industry, Article, Female, Priority Journal, Procedures, Controlled Study, and Environmental Sustainability.
- The green cluster grouped the keywords Economic and Social Effects, Agriculture, Agricultural Robots, Sustainable Development, Climate Change, Land Use, Greenhouse Gases, Ecosystem, and Biodiversity. The findings revealed a significant variation in the co-occurrence of author keywords in individual articles in the ECAP-FS literature. This demonstrated the scientific field's multifaceted and multidimensional nature. This result is agreement with the work of Orimoloye et al. (2021b).

Figure 7 depicts the frequency of word occurrence of the top 70 most utilised title keywords in ECAP-FS studies. During the research, a word cloud was generated using the titles of published articles that contained the most frequently used keywords in ECAP-FS research. This revealed the most commonly used word or phrase in ECAP-FS research. Within the word cloud on ECAP-FS research, various regions of connections and the most significant words used were determined. For example, COVID-19, food security, agriculture, climate change, ecosystem services, resilience, agricultural production, sustainable development, food system, and China were recognised as the most prevalent or prominent themes in ECAP-FS studies.

\section{Conclusion}

The COVID-19 pandemic has received significant recognition since the outbreak, and serious effort has been expended by researchers around the world in various fields. The present bibliometric analysis of COVID-19 examined the resulting effects on agricultural production and food security research trends from 2016 to April 2021 by means of data acquired from WoS and Scopus. According to our findings in ECAP-FS, there has been an exponential rise in research publications. This indicates that studies on ECAP-FS received increasing attention during last few years especially in 2020 and 2021, most likely due to COVID-19 pandemic related research by authors from different counties of the world like China, USA and the United Kingdom. Furthermore, most of the productive authors in ECAP-FS at the time of this research were from China, possibly because the pandemic was first discovered in Wuhan City. 


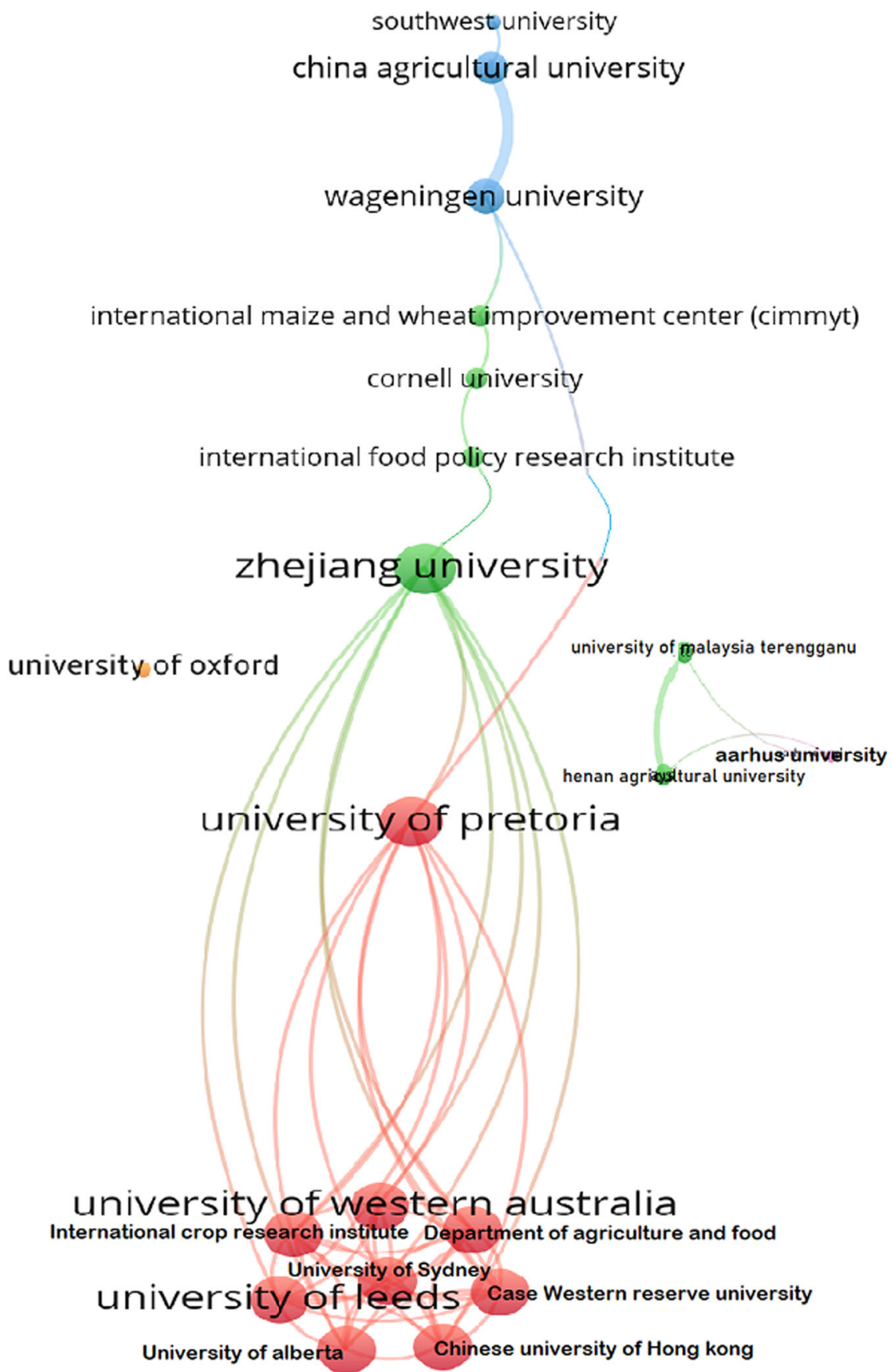

Fig. 5 University collaboration network. The top 20 university collaboration networks on agricultural production and food security research.

The findings of this analysis revealed that few articles came from Africa. In terms of country and institution collaboration networks, few of the countries and institutions collaborated with the countries in Africa except for the University of Pretoria, which had a strong collaboration network on ECAP-FS research during the period of study. According to the word cloud analysis and frequency analysis of the frequently used keywords and keyword-plus demonstrated that the most topical issues in ECAP-FS are COVID-19, food security, agriculture, climate change, agricultural production, sustainable development, biodiversity and sustainability. These results demonstrated the most persistent issues related to ECAP-FS; this was buttressed by another conceptual framework indicator such as keyword co-occurrence networks.
The bibliometric survey performed in this study has some limitations, such as the use of two databases (Scopus and WoS), the strictness of the search keywords and search approach employed, as well as the exclusion of other document types (e.g., conference papers, books chapters, reviews, abstracts, meetings and notes, etc.) and published articles in languages other than English (French, Dutch, Chinese). Despite the limitations, this research seems to be the first bibliometric analysis on ECAP-FSrelated studies, which adds to the evidence base and will drive further studies. Furthermore, WoS and Scopus have greater coverage than other databases, dependable indexing technology that reduces the "indexer effect," and are highly regarded by scientific communities. Other databases, such as ScienceDirect, 


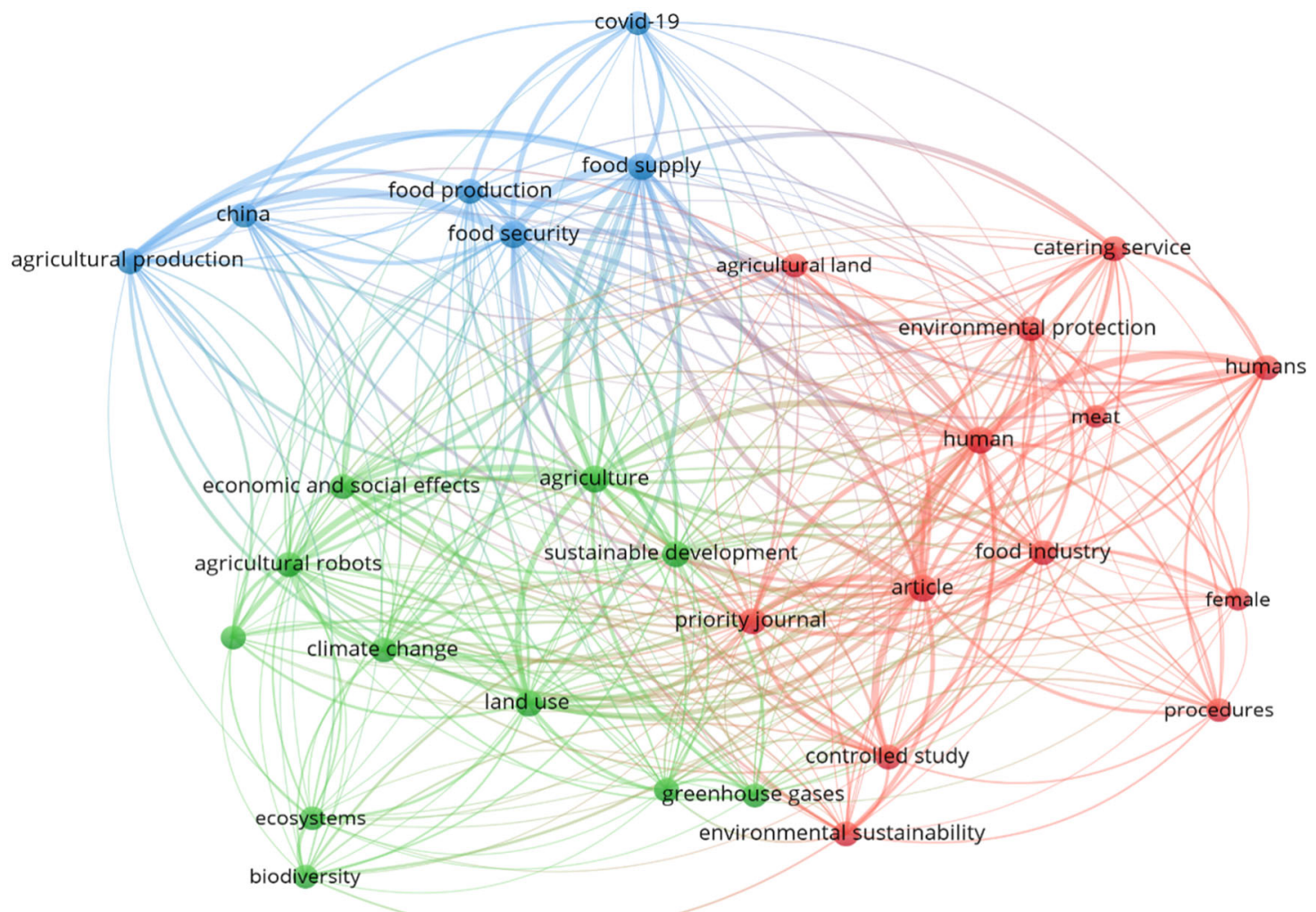

Fig. 6 Co-occurrence network visualization. The co-occurrence network visualisation of 30 keywords and their relationship strength of agricultural production and food security research.

\section{saatial danning sars-cov-2 Sustainable development covid-19 pandemic food systêins sustainable development goals ecosystem services}

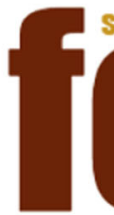
sustainable agriculture
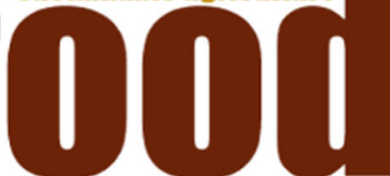

livestock

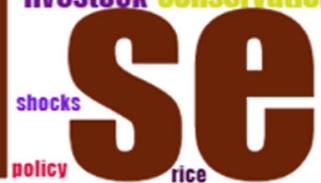

crop diversity agricultural production

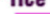
india

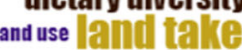

$$
\begin{gathered}
\text { lockdown pandemic } \\
\text { land sharing trade-ofís }
\end{gathered}
$$

land sparing

crisis management

developing countries liangsu province
sustainable land management
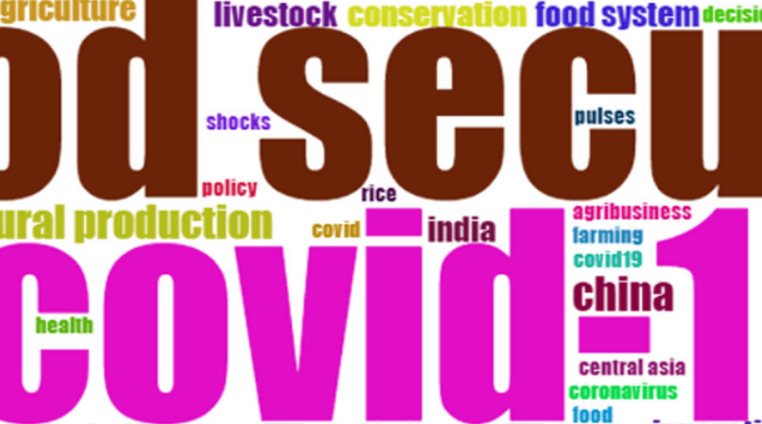
agribusin circular economy

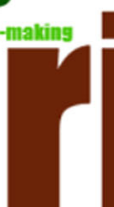
china central asia coronavirus

food innovation
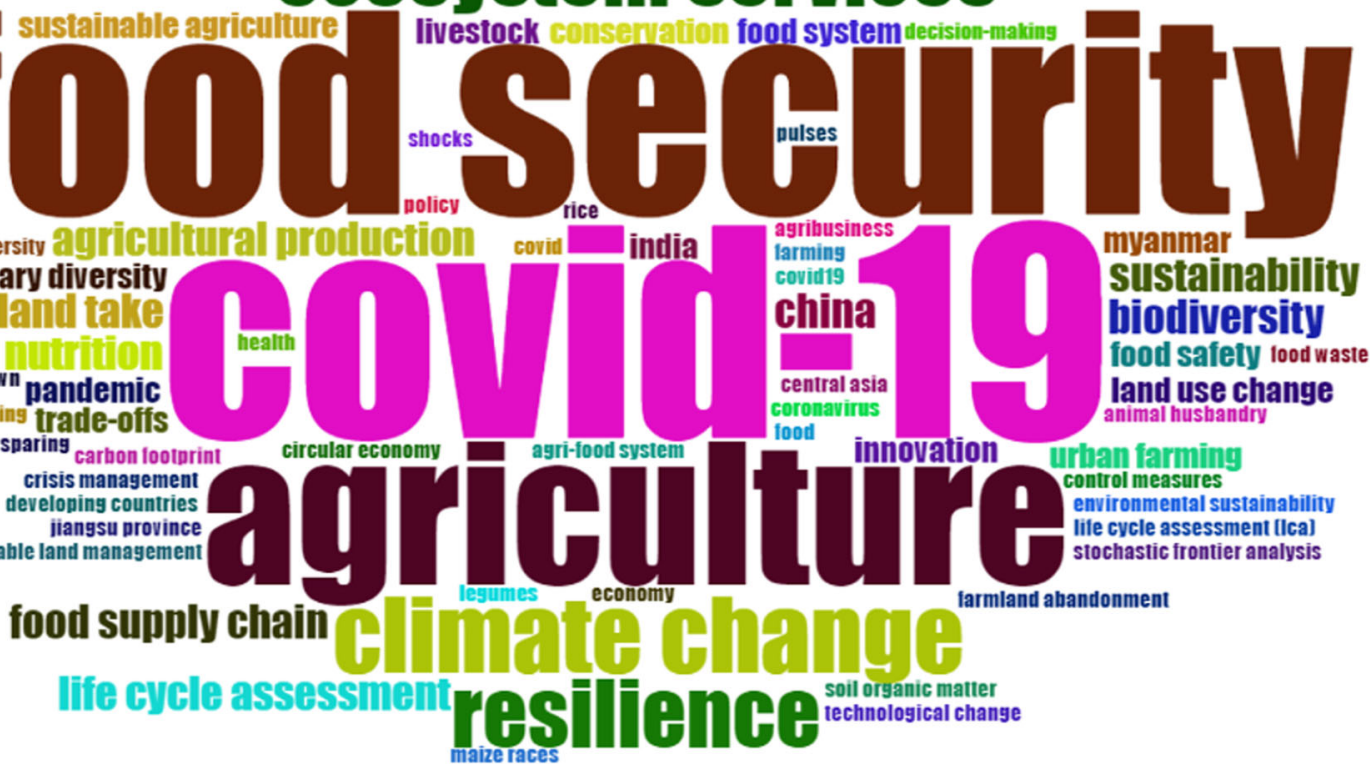

Fig. 7 Word cloud. Word cloud or frequency of word occurrence of the top 70 most often used title keywords in agricultural production and food security research. 
Education Resource Information Center (ERIC), and Directory of Open Access Journals (DOAJ), should be evaluated in future studies.

\section{Data availability}

All data analysed are contained in the paper.

Received: 9 September 2021; Accepted: 8 February 2022;

Published online: 28 February 2022

\section{References}

Alam GM, Khatun MN (2021) Impact of COVID-19 on vegetable supply chain and food security: empirical evidence from Bangladesh. PLoS ONE 16(3):e0248120

Aria M, Cuccurullo C (2017) bibliometrix: An R-tool for comprehensive science mapping analysis. J Informetr 11(4):959-975 https://doi.org/10.1016/ j.joi.2017.08.007

Bai HM (2020) The Socio-economic implications of the Coronavirus pandemic (COVID-19) A Review. ComFin Res 8(4):8-17

Carroll N, Sadowski A, Laila A, Hruska V, Nixon M, Ma DWL, Haines J (2020) The Impact of COVID-19 on Health Behavior, Stress, Financial and Food Security among Middle to High Income Canadian Families with Young Children. Nutrients. 12:2352 https://doi.org/10.3390/nu12082352

Ceballos F, Kannan S, Kramer B (2020) Impacts of a national lockdown on smallholder farmers' income and food security: empirical evidence from two states in India. World Dev 136:105069. https://doi.org/10.1016/j.worlddev.2020.105069

Dev SM (2020) Addressing COVID-19 impacts on agriculture, food security, and livelihoods in India, IFPRI book chapters, in: COVID-19 and global food security, ch. 7, International Food Policy Research Institute (IFPRI), p 33-35

Devereux S, Béné C, Hoddinott J (2020) Conceptualising COVID-19's impacts on household food security. Food Secur 12(4):769-772

Echchakoui S (2020) Why and how to merge Scopus and Web of Science during bibliometric analysis: the case of sales force literature from 1912 to 2019. J Market Anal 8(3):165-184. https://doi.org/10.1057/s41270-020-00081-9

Ekundayo TC, Okoh AI (2018) A global bibliometric analysis of Plesiomonasrelated research (1990-2017). PLoS ONE 13(11):1-18. https://doi.org/ 10.1371/journal.pone.0207655

El Mohadab M, Bouikhalene B, Safi S (2020) Bibliometric method for mapping the state of the art of scientific production in Covid-19. Chaos Solitons Fractals 139:110052

Elsahoryi N, Al-sayyed H, Odeh M, Mcgrattan A, Hammad F (2020) Effect of Covid-19 on food security: a cross-sectional survey. Clin Nutr ESPEN 40:171-178. https://doi.org/10.1016/j.clnesp.2020.09.026

Food and Agricultural Organisation (2020) Sustainable crop production and COVID-19. https://doi.org/10.4060/ca8807en

Foyer CH, Lam HM, Nguyen HT, Siddique KH, Varshney RK, Colmer TD, Considine MJ (2016) Neglecting legumes has compromised human health and sustainable food production. Nat Plants 2(8):1-10

Genkin AS, Mikheev AA (2020) Influence of coronavirus crisis on food industry economy. Foods Raw Mater 8: 2

Gong B (2018) Agricultural reforms and production in China: changes in provincial production function and productivity in 1978-2015 Stochastic frontier analysis. Semi-varying coefficient model China's agricultural production and productivity. Rural reforms multi-segment industry. https://doi.org/10.1016/ j.jdeveco.2017.12.005

Gong B, Zhang S, Liu X, Chen KZ (2021) The Zoonotic diseases, agricultural production, and impact channels: evidence from China. Global Food Secur28:100463. https://doi.org/10.1016/j.gfs.2020.100463

Gregorio GB, Ancog RC (2020) Assessing the impact of the COVID-19 pandemic on agricultural production in Southeast Asia. Toward Transform Change Agric Food Syst 17(1):1-14

Guerrero-Baena MD, Gómez-Limón JA, Fruet Cardozo JV (2014) Are multicriteria decision-making techniques useful for solving corporate finance problems? A bibliometric analysis. Rev de Metod Cuantitativos para la Econ y la Empres 17:60-79

Hamidah I, Pawinanto RE, Mulyanti B, Yunas J (2021) A bibliometric analysis of micro electromechanical system energy harvester research. Heliyon 7(3):e06406. https://doi.org/10.1016/j.heliyon.2021.e06406

Hanna R, Xu Y, Victor DG (2020) After COVID-19, green investment must deliver jobs to get political traction. Nature 582:178-180

Hart MM, Antunes PM, Chaudhary VB, Abbott LK (2018) Fungal inoculants in the field: Is the reward greater than the risk? Funct Ecol 32(1):126-135

KC KB, Dias GM, Veeramani A, Swanton CJ, Fraser D, Steinke D, Fraser ED (2018) When too much isn't enough: does current food production meet global nutritional needs? PLoS ONE 13(10):e0205683
Laborde D, Martin W, Vos R (2020a) Poverty and food insecurity could grow dramatically as COVID-19 spreads. International Food Policy Research Institute (IFPRI), Washington

Laborde D, Martin W, Swinnen J, Vos R (2020b) COVID-19 risks to global food security. Science 369(6503):500-502

Leydesdorff L (2009) How are new citation-based journal indicators adding to the bibliometric toolbox? J Am Soc Inf Sci Technol 60(7):1327-1336

Mishra D, Luo Z, Jiang S, Papadopoulos T, Dubey R (2017) A bibliographic study on big data: concepts, trends and challenges. Bus Process Manag J 23:555-573. https://doi.org/10.1108/BPMJ-10-2015-0149

Mottaleb KA, Mainuddin M, Sonobe T (2020) COVID-19 induced economic loss and ensuring food security for vulnerable groups: policy implications from Bangladesh. PLoS ONE 15(10):e0240709. https://doi.org/10.1371/ journal.pone.0240709

Nchanji EB, Lutomia CK (2021) Regional impact of COVID-19 on the production and food security of common bean smallholder farmers in Sub-Saharan Africa: implication for SDG's. Global Food Secur 29:100524

Nechifor V, Priscila M, Ferrari E, Laichena J, Kihiu E, Omanyo D, Musamali R, Kiriga B (2021) Food security and welfare changes under COVID-19 in SubSaharan Africa: impacts and responses in Kenya. Global Food Secur 28:100514. https://doi.org/10.1016/j.gfs.2021.100514

Nyam YS, Kotir JH, Jordaan AJ, Ogundeji AA, Adetoro AA, Orimoloye IR (2020) Towards understanding and sustaining natural resource systems through the systems perspective: a systematic evaluation. Sustainability 12(23):9871

Orimoloye IR, Ololade OO (2021) Global trends assessment of environmental health degradation studies from 1990 to 2018. Environ Dev Sustainabil 23(3):3251-3264

Orimoloye IR, Belle JA, Olusola AO, Busayo ET, Ololade OO (2021a) Spatial assessment of drought disasters, vulnerability, severity and water shortages: a potential drought disaster mitigation strategy. Nat Hazards 105(3):2735-2754

Orimoloye IR, Belle JA, Ololade OO (2021b) Exploring the emerging evolution trends of disaster risk reduction research: a global scenario. Int J Environ Sci Technol 18(3):673-690

Park JY, Nagy Z (2018) Comprehensive analysis of the relationship between thermal comfort and building control research-a data-driven literature review. Renew Sustain Energy Rev 82:2664-2679

Petetin L (2020) The COVID-19 crisis: an opportunity to integrate food democracy into post-pandemic food systems. Eur J Risk Regul 11(2):326-336

Pu M, Zhong Y (2020) Rising concerns over agricultural production as COVID-19 spreads: lessons from China. Global Food Secur 26:100409. https://doi.org/ 10.1016/j.gfs.2020.100409

Shaffril HAM, Krauss SE, Samsuddin SF (2018) A systematic review on Asian's farmers' adaptation practices towards climate change. Sci Total Environ 644:683-695. https://doi.org/10.1016/j.scitotenv.2018.06.349

Singh S, Kumar R, Panchal R, Tiwari MK (2021) Impact of COVID-19 on logistics systems and disruptions in food supply chain. Int $\mathrm{J}$ Prod Res 59(7):1993-2008. https://doi.org/10.1080/00207543.2020.1792000

Tamru S, Hirvonen K, Minten B (2020) Impacts of the COVID-19 crisis on vegetable value chains in Ethiopia. IFPRI book chapters, International Food Policy Research Institute (IFPRI) pp 81-83. https://doi.org/10.2499/ p15738coll2.133762_18

Tranfield D, Denyer D, Smart P (2003) Towards a methodology for developing evidence-informed management knowledge by means of systematic review. Br J Manag 14(3):207-222. https://doi.org/10.1111/1467-8551.00375

Van Eck NJ, Waltman L (2017) Citation-based clustering of publications using CitNetExplorer and VOSviewer. Scientometrics 111(2):1053-1070. https:// doi.org/10.1007/s11192-017-2300-7

Van Eck NJ, Waltman L (2009) VOSviewer: a computer program for bibliometric mapping. In: Larsen B, \& Leta J (eds) 12th International conference on Scientometrics and Informetrics, ISSI 2009, pp. 886-897

Xu Z, Elomri A, El Omri A, Kerbache L, Liu H (2021) The compounded effects of COVID-19 pandemic and desert locust outbreak on food security and food supply chain. Sustainability 13(3):1063

Zhang S, Wang S, Yuan L, Liu X, Gong B (2020) The impact of epidemics on agricultural production and forecast of COVID-19. China Agric Econ Rev Emerald Group Publishing 12(3):409-425

Zhang W, Yuan H (2019) A bibliometric analysis of energy performance contracting research from 2008 to 2018. Sustainability 11(13):3548

\section{Competing interests}

The author declares no competing interests.

\section{Ethical approval}

This article does not contain any studies with human participants performed by any of the authors. 


\section{Informed consent}

This article does not contain any studies with human participants performed by any of the authors.

\section{Additional information}

Correspondence and requests for materials should be addressed to Abiodun A. Ogundeji.

Reprints and permission information is available at http://www.nature.com/reprints

Publisher's note Springer Nature remains neutral with regard to jurisdictional claims in published maps and institutional affiliations. (c) (i) Open Access This article is licensed under a Creative Commons Attribution 4.0 International License, which permits use, sharing, adaptation, distribution and reproduction in any medium or format, as long as you give appropriate credit to the original author(s) and the source, provide a link to the Creative Commons license, and indicate if changes were made. The images or other third party material in this article are included in the article's Creative Commons license, unless indicated otherwise in a credit line to the material. If material is not included in the article's Creative Commons license and your intended use is not permitted by statutory regulation or exceeds the permitted use, you will need to obtain permission directly from the copyright holder. To view a copy of this license, visit http://creativecommons.org/licenses/by/4.0/.

(C) The Author(s) 2022 